Portland State University

PDXScholar

1976

\title{
An Exploratory Study Concerning Reasons Given for Termination of Provision of Foster Care
}

Linda Ann Nelson

Portland State University

Follow this and additional works at: https://pdxscholar.library.pdx.edu/open_access_etds

Part of the Social Work Commons

Let us know how access to this document benefits you.

Recommended Citation

Nelson, Linda Ann, "An Exploratory Study Concerning Reasons Given for Termination of Provision of Foster Care" (1976). Dissertations and Theses. Paper 1773.

https://doi.org/10.15760/etd.1773

This Thesis is brought to you for free and open access. It has been accepted for inclusion in Dissertations and Theses by an authorized administrator of PDXScholar. Please contact us if we can make this document more accessible: pdxscholar@pdx.edu. 
AN ABSTRACT OF THE PRACTICUM OF Linda Aun Nelson for the Master of Social Work, presented March 15, 1976.

Title: An Exploratory Study Concerning Reasons Given for J'ermination of Provision of Foster Care

APPROVED BY PRACTICUM ADVISOR:

June Dunn

The purpose of this practicum is to determine reasons given by former foster parents for their termination of provision of foster care. Research was completed through a survey of the literature in the field of foster care and through inquiries with personnel currenty working with foster care programs in Columbia and Multnomah Counties. Utilizing the concerns of the personnel and issues raised in the literature, a questionnaire was developed which was intended specifically for former foster families currentiy residing in Columbia Courty. 48.9 percent of the questionnaires were rcturned.

The results showed that fifty percent of the foster famijies who responded teminated their provision of foster care within two years, with an additional twenty-three pereent teminating witizin two more years, making a total of cuenty whree percent who discontinued foster care within four years. Sixtyone percent issed "no ionger infereeted" as a reason for termirating. This category ivoluded the focter family's cwn children's reactions; foster child related concons such as age, sex, and behavior problens; and situatonel factore such as recreational 
limitations, work, or school changes. An area of concern in this study was the relationship of the agency who administers a foster care program and the reasons foster parents give for discontinuing foster care. The data gathered shows that seventy four percent of these former foster families rated their contact with Columbia County Children's Services Division as either "okay" or "good". 
AN EXPLORATORY STUDY CONCERNING

REASONS GIVEN FOR TERMINATION

OF PROVISION OF FOSTER CARE

by

LINDA ANN NELSON

A practicum submitted in partial fulfillment of the requirements for the degree of

MASTER OF SOCIAL WORK

Portland State University

1976

APPROVED :

June Dunn, MSW

Practicum Advisor 
TABLE OF CONTENTS

PAGE

LIST OF TABLES . . . . . . . . . . . . . . . .

INTRODUCTION . . . . . . . . . . . . . . . . . I 1

SURVEY OF THE LITERATURE . . . . . . . . . . . . . . 2

DESCRIPTION OF STUDY ................... . . .

FINDINGS . . . . . . . . . . . . . . . . . . . . 9

RESULTS AND IMPLICATIONS . . . . . . . . . . . . . 10

SUMMARY AND RECOMMENDATIONS . . . . . . . . . . . . 14

FOOTNOTES . . . . . . . . . . . . . . . . 17

SOURCES CONSULTED . . . . . . . . . . . . . . . . 19

APPENDIX . . . . . . . . . . . . . . . . 22 


\section{LIST OF TABLES}

TABLE

PAGE

I Percentage Distributions of Foster Parents by Length of Tenure with Agency . . . . . . . . . . . . 5

II Reasons for Terminating . . . . . . . . . . . 10

III Relationships with the Agency . . . . . . . . . 10

IV Breakdown According to Tenure . . . . . . . . . . . 11

V Positive Contact Related to Tenure . . . . . . . 12

VI Positive Contact . . . . . . . . . . . . 13 


\section{INTRODUCTION}

A vital part of any foster care program is foster parents. Why foster parents terminate their provision of foster care is, therefore, a matter of great concern to agencies who serve children. This practicum is in response to the expressed desire of personnel at Columbia County Children's Services Division to learn more about why foster parents do withdraw their services from the foster care program.

Foster care is a major need of many children in the United States. Authors of one book published in 1974 quoted the prediction that in 1975 an estimated 302,000 children would be in placement nationwide. They noted that this figure did not include unreported placements or unlicensed foster homes and that it omitted the factor of rotation. This means that the figure of 302,000 could represent a residual group of twenty-five percent of the total number of children cared for in one year, which would indicate that the number of children passing in and out of foster care in 1975 would be closer to $2,000,000 .^{1}$

Ms. Constance McDonigle represented CSD on a television program concerning foster care in Oregon recently. She said that in Oregon around 3,800 children are currently in foster care and that at least 200 others are in need of foster care. ${ }^{2}$ In Columbia County, a rural county in northwest Oregon, sixty-five children presently are in foster care, and the agency estimated that a total of seventy-five to eighty will be in care in the course of one year. Currently seventy foster families are licensed to provide this 
care in Columbia County. Major concerns of the CSD foster care unit are the recruitment of new foster homes and the retention of current ones. More foster parents are needed to insure the quality of foster care, yet if as many foster parents quit as are recruited, the total number remains stable. Personnel at CSD are concerned with the number of people who have terminated provision of foster care and want to discover the reasons behind the terminations. Since little information is readily available, it was decided to conduct an exploratory study with the intent of determining these reasons. Due to rapid social change, a recent population was deemed desirable. Therefore all foster parents who had terminated provision of foster care for Columbia County CSD between January, 1971, and December, 1974, were selected for the study.

\section{SURVEY OF THE LITERATURE}

Even though an extensive body of literature on foster care exists, a number of topics have not been well researched. This lack of research does not minimize the importance of these topics, one of which is reasons given for termination of provision of foster care. Topics that have been explored include the study of the natural parents of the child in foster care: their backgrounds, socioeconomic status, reasons for placing their children in foster care, visitation rights. The children themselves have been studied: their separation problems, adjustment, school involvement, specific groups such as mentally retarded or physically handicapped. Foster parents have not been excluded from their share of the research as long as they remain in a foster care program. 
Studies exist on demographic data, recruitment, differences between "good" and "bad" homes. Placements have been researched: how "successful" they are, types of placements such as group homes. Another topic which has been researched is that of roles: roles of the foster parents, roles of the natural parents, roles of the agency, role ambiguity .

Historically, the "major overriding goal of foster family care has been to provide children with maximum opportunities for healthy development." 3 Attaining this goal has not been easy. Originally foster care was provided for children who either were orphans or who had been abandoned and were living in squalid conditions in the cities. The foster families, who lived in the country, met the basic needs of these children and provided vocational training, generally related to agriculture. However, the type of children in foster care has changed. Their needs and backgrounds vary. There are fewer orphans, but more children born out of wedlock. These are children who usually have been subjected to deprivation and instability in their families and who need intensive service. Maluccio views the present foster care system as a dysfunctional one for three reasons: a large turnover in foster homes; frequent replacement of children in different foster homes; and a chron ic shortage of foster homes, especially now that increasing numbers of women are working outside the home. 4

Concerns foster parents express and problems they face may very well contribute to the decision made by some to terminate their provision of foster care. One major concern appears to be that the addition of a child upsets the equilibrium of the foster family. Foster family 
care is not simply foster parent care. ${ }^{5}$ The placement of a foster child sometimes is deeply threatening to an own child. ${ }^{6}$ One study showed that the ages at which own children seemed to be most affected were between seven and thirteen, that the first year is the hardest, and that difficulties were not as apparent when foster children and own children were not the same age. 7 Any time a new person is added to any group, there is an accompanying change in group dynamics. This holds true for foster families in that the addition of a foster child involves the entire family system and its dynamic equilibrium. 8

Faulty communication with the agency is another problem in the area of foster care. An initial lack of mutual understanding between foster parent applicants and the agency often sets the stage for future difficulties. ${ }^{9}$ Foster parents may feel that their workers are not conveying their concerns to the agency and are neglecting to give them feedback on questions they ask. They feel unable to make their needs known to the agency and to affect policy decisions which concern them. 10 Often all the rules of an agency result in foster parents who have few rights and many responsibilities. ${ }^{11}$ Many foster parents indicate that they feel they do not receive enough cooperation or support from the caseworker. The child in foster care often has been deprived physically and emotionally and will make great demands for love, thus requiring great parental skills. S/he may have a seemingly insatiable need for affection and attention along with a reluctance to interact with an adult.12 A common problem seems to be the willingness of the foster parents to give up on such a child too easily.13 The availability of the caseworker may well determine if the particular placement lasts and 
if the foster family lasts. The actual placement is not the only time of stress for a foster family. Death of a family member, the loss or change of job for a foster parent, a prolonged or serious illness in the family, and problematic behavior of a foster or own child are but a few of the other events which may be stressful.14 Foster parents may make a break with the child or even the agency when circumstances offer the opportunity. Parker noted that often permanent removal of a child was requested when the foster mother had an illness, however brief, or when the foster family moved. 15

A few authors either have made direct comments concerning the reasons why foster parents terminated or alluded to possible reasons. Fanshel included a table in his book which shows the distribution of foster parents by length of tenure with the agency.

TABLE I

PERCENTAGE DISTRIBUTIONS OF FOSTER PARENTS BY LENGTH OF TENURE WITH AGENCY 16

\begin{tabular}{lccc}
\hline $\begin{array}{l}\text { Number of Years } \\
\text { with Agency }\end{array}$ & $\begin{array}{l}\text { Infant } \\
\text { Homes } \\
(\mathrm{N}=62)\end{array}$ & $\begin{array}{c}\text { Non Infant } \\
\text { Homes } \\
(\mathrm{N}=39)\end{array}$ & $\begin{array}{c}\text { Total Group } \\
(\mathrm{N}=101)\end{array}$ \\
\hline 1 or less & $12 \%$ & $25 \%$ & $17 \%$ \\
\hline $1-2$ & $23 \%$ & $29 \%$ & $25 \%$ \\
\hline $3-4$ & $25 \%$ & $10 \%$ & $19 \%$ \\
\hline $5-6$ & $11 \%$ & $10 \%$ & $11 \%$ \\
\hline $7-9$ & $16 \%$ & $8 \%$ & $13 \%$ \\
\hline $10-14$ & $3 \%$ & $10 \%$ & $6 \%$ \\
\hline $15-19$ & $8 \%$ & $8 \%$ & $8 \%$ \\
\hline 20 or more & $2 \%$ & $0 \%$ & $1 \%$ \\
\hline
\end{tabular}

The attrition rate of non infant homes is quite high, with fifty-four percent of those homes terminating within two years. Forty-two percent of all foster homes in this study terminated within two years. Maluccio suggests that many foster parents withdraw after two or three years due 
to stress and dissatisfaction in their role or loss of interest in the program.17 Looking at the table on the prior page, it would appear that non infants are a source of more stress than are infants.

Stone referred to a study in which the one major reason why foster homes were closed in 1965 was ranked. The reason most often given, by forty percent of the population, was "no longer interested." Parents who listed this included those who had had a child from ten to twelve years and who did not want to begin again with a new child; those who said they were "emotionally used up"; and those whose foster children had grown up and left their homes for independent living. Six percent of the population listed employment of the mother as the main reason for closing. Moving, illness, and administrative closings each accounted for less than ten percent. The remaining parents listed a combination of reasons. The category "no longer interested" is so vague and so often used that one wonders how much satisfaction the foster parents received in their role. ${ }^{18}$

The Foster Parent Association and CSD in Multnomah County began researching this topic in 1975. They conducted a telephone interview of 200 former foster parents in an attempt to determine why their homes had been closed. At the time of this report the resulting data was not yet available. A copy of their questionnaire can be found at the end of this report.

DESCRIPTION OF STUDY

\section{Purpose}

This study is exploratory and has as its purpose the determination 
of reasons for termination of foster care services by seventy-one families in Columbia County between January, 1971, and December, 1974.

\section{Methodology}

The first step in this study was to take a systematic survey of the families who had terminated services and to pull those files to read what reasons had been listed for the termination of services. Of the seventeen files pulled, only two had data related to the termination of services. The decision was made to develop and mail a questionnaire designed to elicit reasons for termination to all those families currently living in Columbia County who terminated the provision of foster care between January, 1971, and December, 1974. Al1 seventy-one files were pulled and addresses checked for correctness. At this time demographic data was collected which included age of foster parents, amount of education they had, their income range, the number of own children, whether they had special or regular certification, how long they were certified, and the year the home was closed. To insure privacy, this information was coded. The code number was placed on the questionnaires for future correlation of the information. Since twelve families had moved out of the county, questionnaires were sent to the remaining fifty-nine only. Twelve of these questionnaires were returned with the notation that the families had moved; this left a total of fortyseven respondents. Of these forty-seven, twenty-three completed and mailed back their questionnaires to the researcher. That the twentyfour families who moved out of the county might have terminated their provision of foster care for reasons other than moving is recognized. 
Due to the fact that forwarding addresses were not available for all twenty-four, the decision was made not to send questionnaires to any of them.

Development of questionnaire

In order to obtain the desired information, a questionnaire was developed. The first stage in this process involved talking both with personnel who work in the area of foster care to determine reasons they think foster families terminate services and with former foster families outside Columbia County. A first draft was drawn up utilizing this information and was sent to personnel at Multnomah County CSD who were involyed in a similar study for purposes of obtaining feedback and additional ideas. The questionnaire was revised to include two sections and given to the faculty advisor for this study. The first section lists possible reasons for termination and provides space for additional reasons not included and for explanation of answers. The second section concerns contacts between the foster family and CSD and was included because of the possibility that one cause of termination may be poor relationships with CSD. The questionnaire was again revised and was then taken to the branch director of Columbia County CSD for approval. Next the questionnaire was mailed to the fifty-nine families thought to be currently residing in Columbia County.*

\section{Implementation}

The questionnaires were mailed in October and were accompanied by

\footnotetext{
*See Appendix for questionnaire
} 
a letter requesting that they be returned by November 15, 1975. It reguested the help of the former foster parents in determining why people choose not to continue serving as foster parents. Since only sixteen were returned initially, a follow-up letter was mailed in early December which stressed the importance of the answers and extended the deadline.* It was felt that this letter might encourage some people who had been hesitant to respond, or perhaps simply remind others who had intended to respond yet had forgotten. A broader scope of responses would increase the validity of the study. An additional seven were returned, giving a total of twenty-three returns, or $48.9 \%$ of the possible forty-seven responses.

\section{Limitations.}

The use of mailed questionnaires limits the amount of information that will be elicited. The questionnaire developed was kept as short as possible so that the foster parents would not have to spend a great amount of time in answering it. Personal interviews would have been more fruitful, but were deemed impractical because Columbia County is a rural area and travel expenses would run quite high. Telephone interviews could not be used since a number of the families do not have telephones. Therefore, the use of a mailed questionnaire was considered most appropriate in spite of its built-in limitations.

\section{FINDINGS}

The results of the questionnaire fall into two categories, reasons

\footnotetext{
*See Appendix for letters
} 
for terminating and relationships with the agency. * In turn, reasons for terminating can be divided into three major areas: reasons concerning an individual, reasons involving interpersonal relationships, and environmental reasons. It should be noted that families were able to check more than one reason.

TABLE II

REASONS FOR TERMINATING

\begin{tabular}{|c|c|c|c|c|}
\hline \multicolumn{2}{|l|}{ Individual } & \multicolumn{2}{|l|}{ Interpersonal } & Environmental \\
\hline Poor health & -4 & Change in family & & Moved \\
\hline Age & -5 & Lost interest & -14 & Cost \\
\hline Employment & -1 & Foster child left & -3 & \\
\hline & & Wanted a rest & - & \\
\hline & & Natural parents & - & \\
\hline & & Caseworker unavailable & - & \\
\hline
\end{tabular}

TABLE III

RELATIONSHIPS WITH THE AGENCY

\begin{tabular}{ll|ll}
\hline \multicolumn{2}{c|}{ Positive } & \multicolumn{3}{|c}{ Negative } \\
\hline Contact good & -12 & Inadequate information & -4 \\
\hline Contact okay & -5 & Inadequate money & -1 \\
\hline Adequate information -10 & CSD did not recertify home -3 \\
\hline
\end{tabular}

RESULTS AND IMPLICATIONS

The very fact that twenty-four of the original seventy-one families had moved out of Columbia County at the time of this research is an important reason for the closing of foster homes which should not be overlooked in this study. Even though demographic data had been collected on all seventy-one families, the length of time with the agency was the only demographic data which correlated with the information from the

${ }^{*}$ The number of responses to each item are noted on the questionnaire 
questionnaires. Of the questionnaires sent to the forty-seven families currently living in Columbia County, a total of twenty-three were returned, one of which had the identifying number removed. This one questionnaire was therefore invalid only for inclusion in the following tables. The table below lists the breakdown of the other twentytwo respondents according to the number of years they served as foster parents.

TABLE IV

BREAKDOWN ACCORDING TO TENURE

\begin{tabular}{lcc}
\hline Number of Years & Number of Parents & Percentage \\
\hline Under 1 & 5 & 23 \\
\hline $1-2$ & 6 & 27 \\
\hline $2-4$ & 5 & 23 \\
\hline $4-8$ & 3 & 13.5 \\
\hline 8 or more & 3 & 13.5 \\
\hline
\end{tabular}

Fifty percent of the responding population terminated within two years. The strong tendency towards shorter involvement is further demonstrated by the fact that seventy-three percent of the foster parents who terminated with the agency did so within four years. One foster family had been certified for eighteen years.

The first section of the questionnaire dealt with reasons for termination of provision of foster care. Foster families were able to mark more than one reason. "No longer interested" was marked by sixtyone percent (fourteen) of the twenty-three respondents. Subcategories under this included: too hard on own children (four); foster children not the age wanted (four); and foster children had behavior problems (six). Fifty percent of the families listing this as a reason terminated within the first two years. Only three families who had served 
the agency for more than four years marked this as a reason for closing their homes.

Six families listed "a change in the foster family" as a reason for terminating; five listed "age of foster parents"; four marked "poor health"; and four marked "cost of foster care". All other categories included three or less responses. Only two families checked unavailability of the caseworker when encountering special problems in relation to a foster child as a reason for terminating. Additional comments made by respondents in the space provided included the feeling that the stress on family relationships was too great; a foster child seeing a caseworker cheat on travel expenses; CSD sending a family only boys when they requested girls; and an expression of appreciation for a caseworker who was "great".

The second section of the questionnaire was concerned with the foster family's relationship with the agency. Of the twenty-three respondents, twelve termed their relationship with CSD as "good" and five as "okay". This makes a total of seventeen, or seventy-four percent, who felt fairly positive about their contact with CSD.

TABLE $V$

POSITIVE CONTACT RELATED TO TENURE

\begin{tabular}{lrc}
\hline Number of Years & Positive Contact & Percentage \\
\hline & 7 & 41 \\
\hline Under 2 & 10 & 59 \\
\hline 2 or more & &
\end{tabular}

Table VI on the following page deals with the twenty-two families about whom the number of years with the agency is known, eleven of whom fall in each of the two categories. The data indicates that the longer a 
family is with this agency, the more likely it is that they will consider that their contact with the agency is generally a positive one.

TABLE VI

POSITIVE CONTACT

\begin{tabular}{l|c|c|c|c}
\hline & \multicolumn{2}{c|}{ Families under 2 years } & \multicolumn{2}{c}{ Families with 2 years or more } \\
\hline & Number & Percentage & Number & Percentage \\
\hline & & 63 & 10 & 91 \\
\hline Respondents & 7 & 37 & 1 & 9 \\
\hline No Response & 4 & &
\end{tabular}

Ten families indicated that they felt CSD gave them adequate information and help, and three felt that CSD did not tell them enough about their foster children. Three said CSD did not recertify their homes, and the explanations given indicated that the major problem was their water supply. Although four marked the cost of foster care as being a factor in terminating in section $I$, only one marked inadequate financial help in this section. Perhaps the foster families are not regarding the cost of care and the monthly payments as being the same. Some months the cost of care is higher due to unusual circumstances which may involve the need for extra transportation or babysitters.

The water problems of several families were explained in the space provided, and one family wrote that the agency had given them a child who so disrupted their lives that they would not consider any future dealings with CSD. The family who had been certified for eighteen years said their experiences had been "very rewarding", but that at their age they felt younger parents could better help the children. The results of this study appear to show first, that the foster parent population in Columbia County is a mobile one, with twenty-four of the original seventy-one families studied moving completely out of 
the county and three of the respondents moving within the county. This reason is one over which CSD has no control. It occurs to this researcher that the agency needs to develop a way of predicting mobility at intake interviews so that families who are likely to move will be used for short-term foster care. The loss of interest in foster care, particularly among new foster parents, is an area at which the agency should look more closely. Although only two families indicated that the unavailability of the caseworker was a reason for terminating, a total of seventeen marked poor health, a change in the foster family, cost of foster care, and problems with the natural parents as reasons for termination. One wonders how much impact an involved caseworker and the provision of supportive services, such as homemaker and transportation, could have when foster parents experience such problems.

It appears from the responses to this study that foster families in Columbia County feel that their relationship with CSD is basically positive and that CSD is giving them adequate information regarding the children. There is some indication that at times the agency persuades a family to take a child with whom they can not cope, thus setting that family up for failure and resulting in a situation detrimental to the family, the child, and, ultimately, the agency.

\section{SUMMARY AND RECOMMENDATIONS}

There is a dearth of research on the topic of why foster parents terminate. This study supports what little has been recorded in that fifty percent of the responding families terminated within two years, as compared to forty-two percent in Fanshel's study. "No longer 
interested" was a reason given by sixty-one percent of the respondents in this study and compares to Stone's reported forty percent. The families who responded in this study generally felt positive about their contact with Columbia County CSD.

This study should not end at this point. Twenty-four families did not return their questionnaires. The reasons behind this lack of response are important, for they may reflect new reasons or support current findings for the reasons why they terminated the provision of foster care.

From the data it is apparent that there are a number of reasons given for termination which need not lead into termination. This researcher recommends:

I. That close contact be maintained with new foster families to encourage them and to sustain their interest in the program.

The high number of families who drop out because of a loss of interest in foster care indicates that close contact is needed. Supportive services for families who are experiencing problems such as illness may also serve to keep some families in the program.

II. That former foster families be contacted periodically to assess possible changes in their circumstances and their response to the foster care program.

This would be especially important for those families who listed a change in the family as a reason for termination since babies grow older and people adjust to the death of a family member.

III. That the agency develop a way to identify those families who are likely to move often so that they can be used more appropriately for short-term care.

Since the population of Columbia County is mobile, one must find ways 
to use sensitively the mobile family in the best interests of the child, either for short-term placements or placements in which the foster child can be mobile also. One means of beginning to determine if there are specific characteristics of mobile families would be to gather data on those families who have left the program because they moved.

IV. That the foster families be interviewed personally by an independent interviewer at the time of termination.

This study has given valuable information in identifying reasons for termination and possible factors to be taken into consideration when interviewing prospective foster families. Gathering such information should be continued.

V. That the reasons given for termination of foster care be listed in the files of foster parents.

This information is useful and should be readily available to aid in planning and implementing the foster care program.

VI. That a study be conducted to determine if there is a correlation between reasons foster parents gave for wanting to be foster parents and reasons they give for terminating their services.

Such information would aid the agency in evaluating their foster care program in terms of meeting expectations of foster parents. This information could prove useful in screening potential foster parents.

Foster care is a vital necessity for some seventy-five to eighty children each year in Columbia County. With only seventy foster families, one can not insure that a foster child will be placed with a family who can best meet her or his needs. More foster families are needed. Lowering the turnover rate is one way to meet this need. 
FOOTNOTES

$1_{E}$. A. Lawder, R. G. Andrews, and J. R. Parsons, Five Models of Foster Family Group Homes (New York: Child Welfare League of America, Inc., 1974), p. 24.

${ }^{2}$ KOAP, "Feedback: The Problems and Needs for Foster Parents," 15 January, 1976.

${ }^{3}$ A. N. Maluccio, "Foster family care revisited: problems and prospects," Public Welfare, 31, 2 (1973), p. 12.

${ }^{4}$ Ibid., p. 13.

5 J. R. Wilkes, "The impact of fostering on the foster family," Child Welfare, 53, 6 (1974), p. 374.

${ }^{6} \mathrm{~J}$. Charnley, The Art of Child Placement (Minneapolis: University of Minnesota Press, 1955), p. 179.

7L. Ellis, "Sharing parents with strangers: the role of the group home foster family's own children," Child Welfare, 51, 3 (1972), p. 170 .

${ }^{8}$ D. Kline and H. F. Overstreet, Foster Care of Children: Nurture and Treatment (New York: Columbia University Press, 1972), pp. 8, 219.

9Lawder, p. 10.

$10_{\mathrm{R}}$. Daniels and J. A. Brown, "Foster parents and the agency," Children Today, 2, 3(1973), p. 26.

$11_{A}$. L. Schorr, ed., Children and Decent People (New York: Basic Books, Inc., 1974), p. 42.

$12 \mathrm{~K}$. Close, "An encounter with foster parents," Children, 18, 4 (1971), p. 138 .

${ }^{13}$ Charnley, p. 185 .

${ }^{14} \mathrm{~K}$ line, p. 272.

$15 \mathrm{R}$. A. Parker, Decision in Child Care (London: George Allen \& Unwin, Ltd., 1966), p. 35 .

16D. Fanshel, Foster Parenthood: A Role Analysis (Minneapolis: University of Minnesota Press, 1966), p. 24.

17Maluccio, p. 13. 
18H. D. Stone, Reflections on Foster Care (New York: Child Welfare League of America, Inc., 1969), p. 33. 


\section{SOURCES CONSULTED}

Cautley, P. W., and Aldridge, M. J. "Predicting success for new foster parents." Social Work 20(1): 48-53, 1975.

Cautley, P. W.; Aldridge, M. J.; and Finifter, B. Successful Foster Homes: An Exploratory Study of their Characteristics. Madison, Wisconsin: Foster Homes Research Project, 1966.

Charnley, J. The Art of Child Placement. Minneapolis: University of Minnesota Press, 1955.

Close, K. "An encounter with foster parents." Children 18(4): 138$142,1971$.

Connet, E., et al. "A Descriptive Analysis of a Metropolitan Foster Parent Population as an Indicator for Recruitment." Group practicum, Portland State University, 1973.

Daniels, R., and Brown, J. A. "Foster parents and the agency." Children Today 2(3): 25-27, 1973.

Davids, L. "Foster fatherhood: the untapped resource." Child Welfare 52(2): 100-108, 1973.

Dinnage, R., and Pringle, M. L. K. Foster Home Care: Facts and Fallacies. London: Longmans, Grenn \& Co., Ltd., 1967.

Dorgan, M. R. "Initiating a program of foster parent education." Child Welfare 53(9): 588-593, 1974.

Ellis, L. "Sharing parents with strangers: the role of the group home foster family's own children." Child Welfare 51(3): 165-170, 1972 .

Fanshe1, D. Foster Parenthood: A Role Analysis. Minneapolis: University of Minnesota Press, 1966.

Felker, E. H. Foster Parenting Young Children: Guidelines from a Foster Parent. New York: Child Welfare League of America, 1974.

Hughes, J., et al. "A Demographic Study Based upon Income, Age and Education Variables as Related to the Willingness or Unwillingness to Accept Foster Children." Group practicum, Portland State University, 1970.

Hutchins, K. et al. "Children without Futures: A Feasibility Study Comparing Characteristics of Families who Have Children Placed in Long and Short-Term Foster Foster Care." Group practicum, Portland State University, 1972. 
Jenkins, S., and Sauber, M. Paths to Child Placement: Family Situations Prior to Foster Care. New York: Community Council of Greater New York, 1966.

Kline, D., and Overstreet, M. K. Foster Care of Children: Nurture and Treatment. New York: Columbia University Press, 1972.

KOAP. "Feedback: The Problem and Needs for Foster Care." 15 January 1976 .

Lawder, E. A.; Andrews, R. G.; and Parsons, J. R. Five Models of Foster Family Group Homes. New York: Child Welfare League of America, Inc., 1974 .

Maluccio, A. N. "Foster family care revisited: problems and prospects." Public Welfare 31(2): 12-17, 1973.

O'Regan, G. W. "Foster family care for children with mental retardation: parents of other retarded children are ready resources." Children Today 31(1): 20-24, 36-37, 1974 .

Parker, R. A. Decision in Child Care. London: George Allen \& Unwin, Ltd., 1966.

Petersen, J. C., and Pierce, A. D. "Socioeconomic characteristics of foster parents." Child Welfare 53(5): 295-304, 1974.

Reistroffer, M. E. "Participation of foster parents in decision making: the concept of collegiality." Child Welfare 51(1): 25-29, 1972.

Schorr, A. L., ed. Children and Decent People. New York: Basic Books, Inc., 1974 .

Sekora, D. V. "Foster Family Care for the Aged." Practicum, Portland State University, 1971.

Shah, C. P. "Assessing needs and board rates for handicapped children in foster family care: progress report." Child Welfare 53(1): $31-38,1974$.

Shyne, A. W. The Need for Foster Care. New York: Child Welfare League of America, Inc., 1969.

Simmons, G.; Gumpert, J.; and Rothman, B. "Natural parents as partner in child care placement." Social Casework 54(4): 224-232, 1973.

Simonts, J. F. "A foster home for crisis placements." Child Welfare 52(2): $82-90,1973$.

Stone, H. D., ed. Foster Care in Question: A National Reassessment by Twenty-One Experts. New York: Child Welfare League of America, Inc., 1970. 
Stone, H. D. Reflections on Foster Care. New York: Child Welfare League of America, Inc., 1969.

Taylor, J. L. "Remedial education of children in foster care." Child Welfare 52(2): 123-128, 1973.

Wilkes, J. R. "The impact of fostering on the foster family." Child Welfare 53(6): 373-379, 1974.

Wolins, M. Selecting Foster Parents: The Ideal and the Reality. New York: Columbia University Press, 1963. 
I. Please put X's in the blank in front of the statement or statements that explain why your family decided not to continue providing foster care.

4 poor health

5 age of foster parents

1 foster mother became employed outside the home

6 a change in the foster family

$\frac{1}{2}$ child(ren) born
$\frac{1}{4}$ older child(ren) left home
$\underline{0}$ foster parents separated or divorced

3 foster family moved to another house Did you consider having this house certified? I Yes 2 No Please explain.

14 foster family no longer interested

4 too hard on own child(ren) to have foster child(ren)

$\overline{4}$ foster child(ren) not the age we wanted

$\underline{2}$ foster child(ren) not the sex we wanted

$\frac{1}{6}$ foster child(ren) limited our recreational activities

$\frac{6}{6}$ foster child(ren) had behavior problems

$\frac{6}{6}$ other. Please explain. a. foster parents were too young

3 foster child(ren) left and we didn't want more back to school and Please explain.

wife to work

c. foster child

3 foster family wanted to rest despised women Please explain. d. had to assume

care of daughter

e. foster

4 the care of foster children cost more than we received children

3 natural parents caused problems

\begin{tabular}{ll}
$\frac{1}{1}$ interfered with the child(ren) & had no children \\
$\frac{0}{2}$ visited the child(ren) too often & For this home \\
$\frac{1}{1}$ othitized us & \\
\hline
\end{tabular}

2 caseworker was not available when we had problems, such as

0 foster child(ren) had problems at school

$\overline{0}$ foster child(ren) needed dental or medical care

1 foster child(ren) were discipline problems in the home

$\underline{1}$ natural parents interfered 
Page 2

Please write any additional reasons why you did not continue being a foster family and explain any reasons you checked.

II. Please put X's in the blank in front of the statement or statements that describes your contacts with Children's Services Division.

5 contact with CSD was okay

12 contact with CSD was good

1 CSD did not give us enough financial help

0 CSD interfered too much with our family

10 CSD gave us adequate information and help

3 CSD did not tell us enough about the foster child(ren) we had

1 CSD did not tell us enough about the family relationships, or the lack of family relationships of the foster child(ren)

3 CSD did not recertify our home

How did your contacts with CSD influence your decision to discontinue providing foster care?

Feel free to explain the reasons you checked and to make additional comments.

Thank you very much for your help. 
October 20, 1975

Dear former foster family,

Foster care is a very important need of many children. In the past you have provided this service for children, but you no longer do so. Your opinion about the foster care program and your experiences with it are important, as are your reasons for deciding not to continue providing foster care. I would like to know these reasons. Columbia County Children's Services Division would also like to know them in order to determine what changes need to be made in their foster care program. To discover these reasons, I need your help.

I am a graduate student in the School of Social Work at Portland State University. This past year, from October 1974 through June 1975, I worked with the foster care program at Columbia County CSD. One of my jobs was that of recertifying foster homes. A number of families decided to discontinue providing foster care. I found out that this happens fairly often -- that, in fact, close to 100 families have made this decision since January 1970. You are one of those families.

Enclosed is a two-page questionnaire which has two sections. The first section lists possible reasons for your decision not to recertify. The second section asks for information about your contacts with CSD. I would appreciate your completing both sections and mailing the questionnaire to me as soon as possible, and no later than November 15, 1975. A stamped envelope is enclosed. All answers will be confidential; you don't have to write your name on the questionnaire. After I tabulate the answers from all the questionnaires, I will send the results to Columbia County CSD in the hope that this information will help them in planning their foster care program.

Thank you very much for taking the time to fill out this questionnaire and for returning it to me. I greatly appreciate your cooperation.

Sincerely yours,

Linda Nelson 
November 25, 1975

Dear former foster family,

Last month I sent fifty questionnaires to families in Columbia County who had decided not to continue providing foster care. Of these fifty, I have had sixteen returned to me. If you have not yet mailed back your questionnaire, I hope you will decide to do so. Finding out why families decided not to continue being foster families is very important, for foster care continues to be needed for many children. Your answers are needed to help determine these reasons. More than that, they are essential. Of course, they will be completely confidential.

Please take the time to fill out and mail the questionnaire to me if you have not already done so. Your help is greatly appreciated.

Thank you very much,

Linda Nelson 
Please answer all of the following questions, be sure to make only one response for each question. Please feel free to ask questions or make comments about the general purpose of the questionnaire or its clarification.

1. How many years were you in the foster parent program?
a. Under one year
b. One to two years
c. Two to five years
d. More than five years

2. Which age group were you in when you left the foster parent program?
a. 21 through 25
b. 26 through 30
c. 31 through 35
d. 36 through 40
e. 41 through 45
f. 46 through 50
g. 51 through 55
h. 56 through 60
i. 61 through 65
j. 66 through 70

3. What sex are you?
a. Female
b. Male

4. How many children of your own (not counting foster children) did you have living at home when you were a foster parent?
a. None
b. One
c. Two
d. Three
e. Four
f. Five
g. Six
h. More than six

5. What type of foster children did you have?

a. Mostly teenagers__ b. Mostly non-teenagers

c. Infants

6. Were your foster children mostly?
a. Girls
b. Boys
c. Both

7. Were most of your foster children
a. Just runaways
b. Had a lot of other problems other than running away
c. Displaced infants
d. Handicapped
e. Other

8. When one of your foster children had a medical problem, was it easy to obtain CSD paid-for help?
a. Yes
b. No

9. When one of your foster children had a dental problem, was it easy to obtain CSD paid-for help?
a. Yes
b. No

10. Were you able to get proper psychological or psychiatric help for your foster children when such help had been recommended by a 
physician, social worker, or other specialist?
a. Yes
b. No

11. Did you feel there was

a. Too much guidance from CSD on how you should handle your foster children

b. Not enough guidance from CSD and you wish there had been more adequate guidance

12. In general, how would you rate the CSD back up services?
a. Excellent
b. Good
c. Fair
d. Poor

13. Do you feel you were paid enough for the service you rendered to the community?
a. Yes
b. No

14. In economic terms, would you say that
a. You broke even
b. Made some profit
c. Lost money
d. Made a lot of profit

15. What was your main reason for leaving the foster parent program?

a. Inadequate funds paid by CSD for foster child care

b. Lack of sufficient back up services

c. Moved away from the area or to a much smaller dwelling

d. A personal reason such as your health, divorce, marriage

e. Became too attached to children and it was too upsetting when they were moved

f. The foster children were just too much to handle

g. Not kept informed regarding case plan

h. Found employment outside the home

i. Other

16. For which reason would you consider becoming a foster parent again?

a. Would never consider doing it again

b. If the back up services were improved

c. If foster care payments were to be increased by $50 \%$

17. In your opinion, how well did CSD match foster children (their personality) to the personality characteristics of your family?

a. Poorly matched

b. Not very well, but probably the best match that could be made under the circumstances

c. The foster children you had were very well matched with your family setting

18. While you were a foster parent, did you experience any of the following

a. A lot of physical pain

b. A lot of anxiety brought about by the foster children

c. Personal anxiety about divorce, jobs, money, death, or other 
personal psychic pain

d. You found that in this period of life you were relatively free of most anxieties, worry, physical pain, and quite happy the way things were

19. When you were a foster parent did you know about the Foster Parents Association?
a. Yes
b. No

20. Where did you learn about the Foster Parents Assocaition?
a. CSD
b. Other Foster Parents
c. Media (radio, TV, printed materials)
d. By word of mouth

21. Was the Foster Parents Association helpful?
a. Yes
b. No

22. How would you characterize your church affiliation?
a. Very active
b. Moderately active
c. Non-active

23. Did you receive sufficient background about the child when he was placed in your home?
a. Yes
b. No

24. Did your experience with Natural Parents cause you
a. extreme distress
c. good
b. moderate distress
d. excellent

25. My income between
a. 0 to 5,000
b. 5,000 to $7 \overline{, 500}$
c. 7,500 to 10,000
d. 10,000 to 15,000
e. Over 15,000

26. After you inquired about foster care, how long was it before you were contacted?
a. Within 7 days
b. Within 30 days
c. Within 90 days
d. Over 90 days

(This questionnaire was prepared by CSD and the Foster Parents Association in Multnomah County) 